\title{
Effects of fluorocarbon propellants on respiratory flow and $\mathrm{ECG}^{1}$
}

\author{
F. VALIĆ, ZDENKA SKURIĆ, Ž. BANTIĆ ${ }^{2}$, M. RUDAR ${ }^{3}$, AND \\ M. HEĆEJ4 \\ ${ }^{2}$ From the Andrija Stampar School of Public Health, University of Zagreb, ${ }^{3}$ Department of Medicine at the \\ Mladen Stojanović University Hospital, and the ${ }^{4}$ Chromos-Katran-Kutrilin Chemical Works, Zagreb, \\ Yugoslavia
}

ABSTRACT Ten subjects were exposed to the propellants freon 11, freon 12, freon 114, to two mixtures of freon 11 and 12 and to a mixture of freon 12 and 114 . The length of exposure was 15, 45 or 60 seconds. Maximum expiratory flow-volume (MEF) curves and ECG were recorded before, and intermittently up to 1 hour after, exposure. Breathing level concentrations of propellants during exposure were determined by gas chromatography. All freons induced biphasic reduction of ventilatory capacity on inhalation. The first fall occurred within a few minutes of exposure while the second was delayed 13-30 minutes after exposure. The effects of mixtures were greater than those of individual freons. The relative fall in MEF $75 \%$ was more pronounced than that in MEF $50 \%$. No clear-cut pathological changes in ECG were found. Nevertheless, most subjects developed variations in heart rate exceeding those noted before exposure. In a few cases inversion of the $\mathrm{T}$ wave, and in one case atrioventricular block, were observed.

Studies of the effects of commonly used commercial aerosols (spray and aerosol are interchangeable terms) on respiratory function (Valić et al., 1974; Žuškin and Bouhuys, 1974; Žuškin et al., 1974) have shown that the majority of such aerosols exert an effect on the ventilatory capacity of the lung. On exposing a cohort of young healthy subjects to a series of commercial aerosols (a body deodorant, an air freshener, an air disinfectant, a furniture polish, a spot remover, a shoe spray, a glass defroster, and five different hair sprays) we observed a significant and immediate reduction of ventilatory capacity on inhalation. The effect varied between aerosols and between subjects but was significant in every instance. The ventilatory capacity did not regain the pre-exposure level within an hour of exposure. The effects were not clinically alarming but highly statistically significant $(P<0.01)$. Maximum reduction in the one-second expiratory volume $\left(F V_{1.0}\right)$ ranged from 3.2 to $4.4 \%$, in the maximum

${ }^{1}$ Presented in part at the XVIII International Congress of Occupational Health, Brighton, September 1975.

Address for correspondence: Professor F. Valić, School of Public Health, Medical Faculty, University of Zagreb, Rockefellerova 4, pret. 770, 41000 Zagreb, Yugoslavia.

Received for publication 7 January 1976 Accepted for publication 10 March 1976 expiratory flow at $50 \%$ of the control vital capacity (MEF 50\%) from 4.8 to $8.4 \%$, and the reduction in the maximum expiratory flow at $75 \%$ of the control vital capacity (MEF $75 \%$ ) was as much as $15 \cdot 1 \%$.

In a separate epidemiological study of a group of hairdressers who applied hair sprays in the course of their work, we found a significant acute reduction in ventilatory capacity over the working period. The changes were clinically mild, but statistically significant $(P<0.01)$. The mean acute reduction in MEF $75 \%$, the test indicating changes in the small airways, was found to be $15 \%$, a drop far from negligible.

Our experiments concerning the effects of various commercial sprays on pig lung tissue have shown that some of the components of the sprays liberated histamine from the tissue (Skurić et al., 1975). The amounts of spray causing a significant histamine release were greater than those inhaled during normal application. It therefore remains questionable whether the reduction in ventilatory capacity could be attributable, at least in part, to the mechanism of smooth muscle contraction of bronchi and/or bronchioles.

In our attempts to establish which of the spray components are responsible for ventilatory capacity reduction, we have found that solvents are likely to 
be the most active components (Valić et al., 1974) and that some resins also appear to play a part (Skurić et al., 1975). However, the effect of propellant gases has not been elucidated.

Speizer et al. (1968) relate the increased mortality from asthma to a more frequent application of bronchodilating aerosols. Bass (1970) and Fraser $e t$ al. (1971) believe that lethal cardiac arrhythmias caused by the inhalation of propellant aerosols are a frequent cause of death. Several authors have found electrocardiographic changes in anaesthetised experimental animals exposed to various freons (Taylor and Harris, 1970; Stilinović et al., 1972; Flowers and Horan, 1972, 1973; Eagle et al., 1972). Brooks et al. (1972) described an increase in airway resistance but no electrocardiographic changes except extrasystoles in some asthmatic patients exposed to freon 132.

In contrast, other authors report that they have not observed any cardiac changes following exposure to propellant gases. Silverglade $(1971,1972)$ did not find any changes in animals, while Paulet and Chevrier (1969), Paulet and Desbrousses (1969), and Paulet et al. (1969) found no changes either in animals or in humans. Joannides (1971) did not observe any untoward reactions in patients with chronic bronchitis who used bronchodilating aerosols, nor were there any changes in the ECG of two subjects exposed to freon 12, studied by Azar $e t$ al. (1972). A number of authors do not believe that deaths in asthma are related to the use of aerosols (Paterson et al., 1971; Silverglade, 1973; Lancet, 1975).

Most of the investigations cited were performed on anaesthetised animals. As anaesthetics were an additional agent to which animals were exposed, the measured effects were not the consequence of exposure to propellants only. Most human studies have been conducted on patients. We wanted to find out whether exposure to the most frequently used propellants, under conditions resembling those under which commercial sprays are normally used, would bring about changes in the ventilatory capacity and/or conduction and cardiac rhythm. To this end, we exposed a group of 10 healthy young volunteers to freon 11 , freon 12 , freon 114 , to two mixtures of freon 11 and 12 (50:50 and 10:90 respectively) and to a mixture of freon 12 and 114 (30:70) for 15, 45 and 60 seconds in the first, second and third series of experiments respectively. We recorded changes in MEF $50 \%$, MEF $75 \%$, and ECG in the course of an hour after exposure.

\section{Subjects and methods}

SUBJECTS AND METHOD OF EXPOSURE

Ten male subjects, aged 20-24 years, were exposed to propellant gases which were applied from commercial packs but under somewhat higher pressure than the usual partial pressures of gases in these packs. The gases were applied from a distance of $50 \mathrm{~cm}$ and the subjects were asked to breathe normally during the exposure. Each subject was exposed to only one propellant or mixture of propellants a day. None of the subjects had a history of any cardiovascular or respiratory disease, or was a regular spray user.

ANALYSIS OF PROPELLANTS

The propellants and their mixtures were sampled with glass syringes at the breathing level of the subject, and the samples were immediately injected into the column of the gas chromatograph (Pye-Panchromatograph (stationary phase, 10\% dinonyl phthalate on Chromosorb W 80-100 mesh; carrier gas, argon; column temperature, $50^{\circ} \mathrm{C}$ )).

\section{RECORDING OF SPIROGRAMS AND}

\section{ELECTROCARDIOGRAMS}

Maximum expiratory flow-volume (MEFV) curves were recorded and the MEF $50 \%$ and MEF $75 \%$ (chest three-quarters empty) were read. In our previous studies (Žuškin and Valić, 1972; Valić and Žuškin, 1973) these tests of ventilatory capacity had proved to be more sensitive than standard tests in the assessment of the effects of air pollutants on lung function. Bouhuys has shown that hair spray does not alter total lung capacity (TLC) (Bouhuys et al., 1969; Bouhuys, 1974). It has also been shown that extracts of bronchoconstricting textile dust do not cause changes in TLC (Žuškin et al., 1975). Therefore the changes in MEF $50 \%$ and MEF $75 \%$ indicate changes in maximum expiratory flow rates at equal degrees of lung inflation. This means that valid comparison of MEFV curves before and after exposure to aerosols can be made by superimposing them at the point of maximum inspiration. The curves were recorded by the flow-volume spirometer described by Peters et al., 1969 (Emmerson Company Ltd., Cambridge, Mass., USA). The curve was recorded immediately before the exposure to the propellant (time 0); the subject was then exposed to the propellant for 15 or 45 seconds and the flowvolume curve was recorded $1,2,3,4,5,13,21,30,40$, 50 , and 60 minutes after the start of exposure. In the series of 15 -second exposures electrocardiograms were taken before the exposure and after 7,15 and 55 minutes, with the subject in the supine position. A three-channel electrocardiograph (EI-Niš, Model $300 / 1968$ ) was used, and recordings were made with twelve standard leads (I, II, III, aVR, aVL, aVF, and $V_{1-6}$ ).

In a separate series of experiments the supine subjects were exposed to propellants for 60 seconds. 
Before the exposure period, recordings were taken from all 12 leads in order to exclude any subject with even the slightest electrocardiographic changes. During and after the exposure period continuous ten-minute recordings were taken from the standard leads (I, II, III).

\section{Results}

\section{PROPELLANTS}

The concentrations of propellants in the air which the subjects inhaled for 15 and 60 seconds are presented in Table 1 as the means of three analyses in each experiment. As these concentrations did not change significantly whether exposure was for 15 or

Table 1 Mean breathing level concentrations of propellants during exposures of 15 and 60 seconds

\begin{tabular}{llcc}
\hline Propellant & & $\begin{array}{l}\text { Concentration in air } \\
\left(m g / m^{3} \times 10^{-4}\right)\end{array}$ \\
\cline { 3 - 4 } & & $\begin{array}{c}\text { Length of exposure }(s) \\
15\end{array}$ \\
\hline Freon 11 & & 9.5 & 9.6 \\
Freon 12 & & 13.4 & 13.6 \\
Freon 114 & & 15.0 & 15.0 \\
Freon 11/12 & Freon 11 & 6.1 & 7.0 \\
50:50 & Freon 12 & 7.6 & 8.3 \\
Freon 11/12 & Freon 11 & 1.8 & 1.6 \\
$10: 90$ & Freon 12 & 8.3 & 8.9 \\
Freon 12/114 & Freon 12 & 3.5 & 4.1 \\
30:70 & Freon 114 & 10.0 & 11.2 \\
\hline
\end{tabular}

for 60 seconds, the amounts of propellants inhaled in the three series of experiments were considered to be related approximately to the duration of exposure, that is, to be in the ratio $15: 45: 60$.

\section{CHANGES IN VENTILATORY CAPACITY}

Changes in MEF $50 \%$ after a 45 -second exposure to freon 12, freon 114 and the $30: 70$ mixture of these freons, are presented in Fig. 1 as the means obtained in 10 subjects.

Each propellant brought about a marked fall in MEF $50 \%$ and this was much more pronounced after the exposure to the mixture than to individual freons. All the curves are biphasic with two peaks, the second one being more pronounced. Exposure to the mixture of freon 12 and 114 caused a maximum fall of $11 \cdot 1 \%$. The reduction in flow rate induced by exposure to freon 12 or 114 was much less pronounced (3.4 and $6.0 \%$ respectively).

Fig. 2 shows changes in MEF $75 \%$ after a 45 second exposure to freon 11, freon 12 and to their two mixtures (10:90 and 50:50). The changes were again biphasic and much more pronounced following exposure to mixtures. The maximum reductions in MEF $75 \%$ which were induced by the two mixtures were found to be of similar magnitude (11.7 and $11.2 \%$ respectively), while those caused by freon 11 $(7.8 \%)$ and freon $12(5.6 \%)$ were considerably smaller.

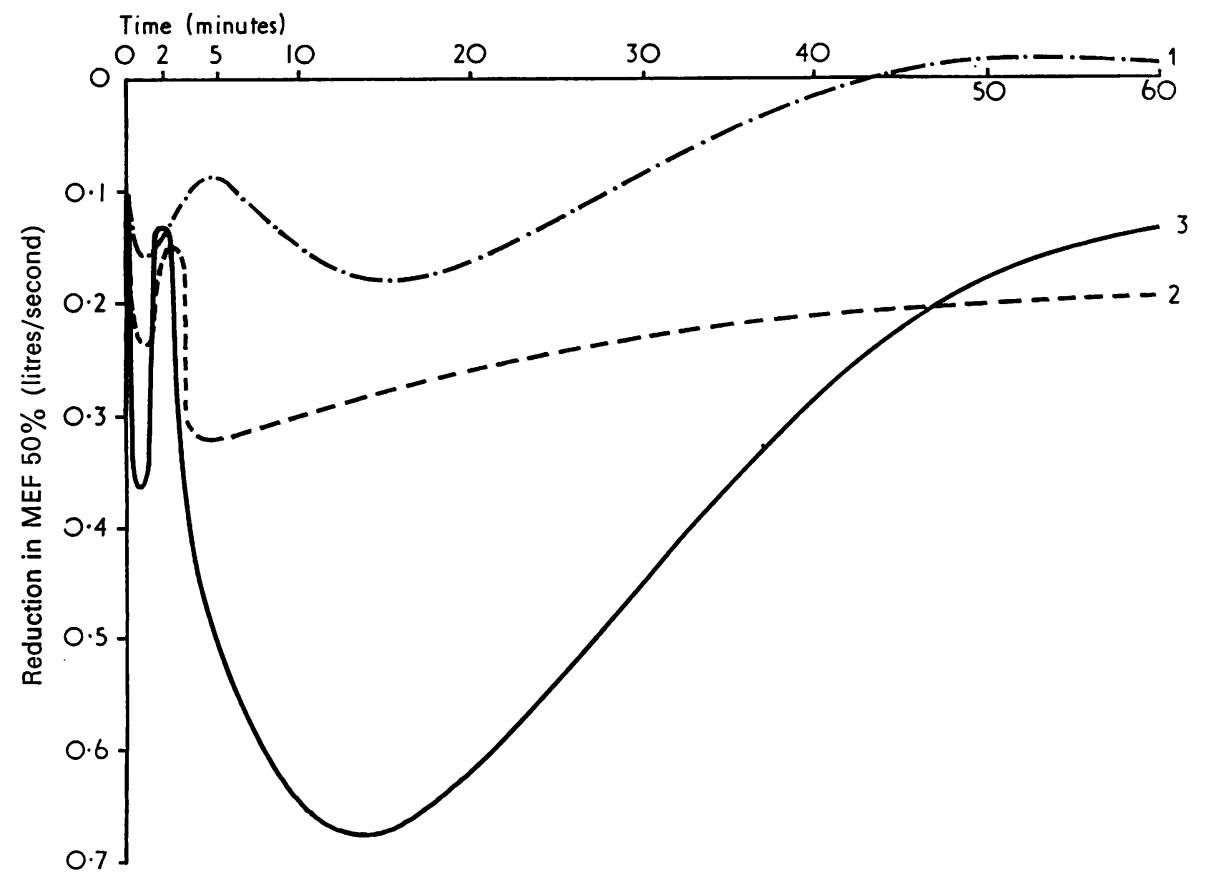

Fig. 1 Change in

MEF $50 \%$ on exposure to freons. 1 = freon 12 , $2=$ freon 114, $3=$ mixture of freon 12 and freon $114(30: 70)$. 


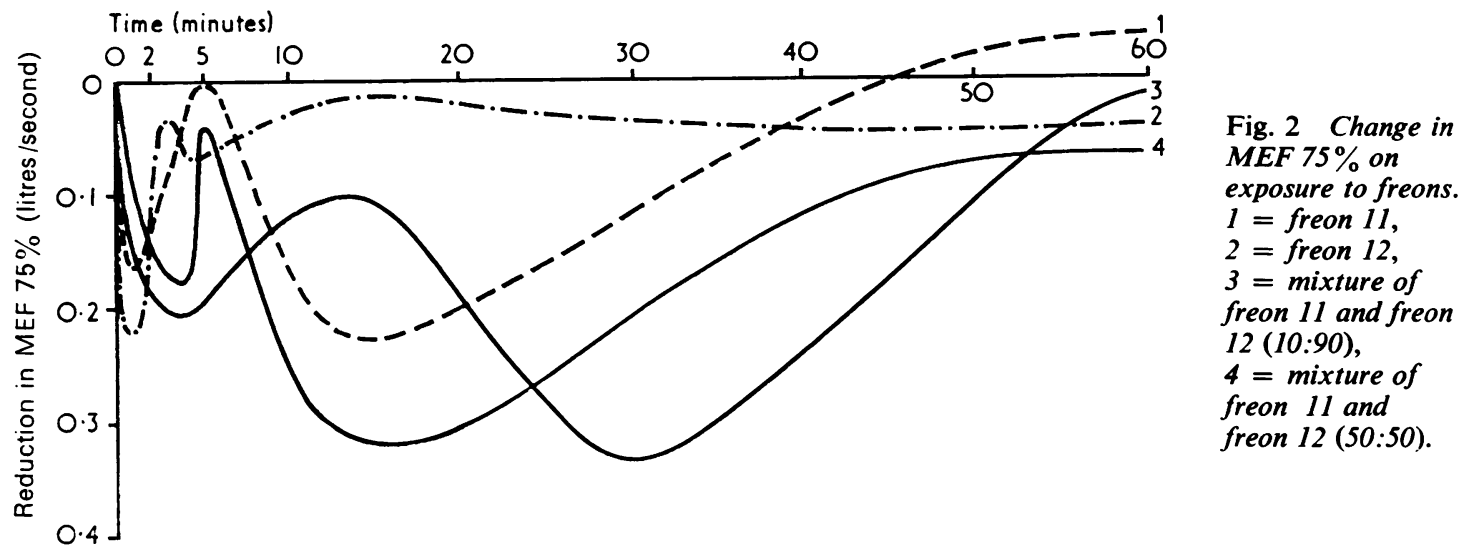

Maximum reductions in MEF $50 \%$ and MEF $75 \%$ following exposure to propellants for 15 seconds are shown in Table 2. It is striking that these reductions were not significantly less than those following 45 second exposure to practically equal concentrations of propellants. With 15-second exposure, as with 45second exposure, the mixtures had more marked effects than the individual freons. The relative maximum reductions in MEF $75 \%$ were slightly greater than those in MEF $50 \%$.

\section{CHANGES IN ECG}

The electrocardiograms of all the subjects, recorded 7,15 and 55 minutes respectively after the start of $15-$ second exposures to propellants, showed a lower heart rate (in some subjects much lower) than those recorded before exposure. Most subjects developed respiratory sinus arrhythmias. In one subject the ECG recorded 15 and 55 minutes after the start of the 15-second exposure to freon 114 showed atrio- ventricular block (PR interval prolonged to $0.4 \mathrm{~s}$ ). Only one ventricular extrasystole was recorded during the whole period of observation of all ten subjects.

In experiments with 60-second exposure and continuous ECG recording there were variations in heart rate similar to those observed after 15-second exposure. Two subjects showed transitory tachycardia and negative $T$ waves within a minute of exposure to freon 11 (Figs. 3 and 4). One of these subjects was excluded from further experiments. In the other, exposure to the mixture of freon 11 and 12 $(10: 90)$ also induced tachycardia and negative $T$ waves, although exposure to other propellants did not induce similar changes in this subject. The subject with AV block 15 and 55 minutes after 15 seconds exposure to freon 114, also suffered intermittent first degree atrioventricular block within the first minute of a 60 -second exposure to the same propellant, and this block persisted throughout the recording period (Fig. 5).

Table 2 Means of the maximum reductions in expiratory flow rate of ten subjects after exposure to various freons

\begin{tabular}{|c|c|c|c|c|c|c|c|c|}
\hline \multirow[t]{2}{*}{ Propellant } & \multicolumn{2}{|c|}{$M E F 50 \%(l / s)$} & \multicolumn{2}{|c|}{ MEF $50 \%(\%$ reduction $)$} & \multicolumn{2}{|c|}{$M E F 75 \%(l / s)$} & \multicolumn{2}{|c|}{ MEF $75 \%$ ( \% reduction $)$} \\
\hline & $A$ & $\boldsymbol{B}$ & $\boldsymbol{A}$ & $\boldsymbol{B}$ & $\boldsymbol{A}$ & $\boldsymbol{B}$ & $A$ & $\boldsymbol{B}$ \\
\hline $\begin{array}{l}\text { Freon 11 } \\
\text { Freon 12 } \\
\text { Freon 114 } \\
\text { Freon 11/12 }\end{array}$ & $\begin{array}{l}0.36 \\
0.13 \\
0.55\end{array}$ & $\begin{array}{l}0.46 \\
0.27 \\
0.30\end{array}$ & $\begin{array}{l}6 \cdot 4 \\
2 \cdot 4 \\
9 \cdot 6\end{array}$ & $\begin{array}{l}8 \cdot 1 \\
4 \cdot 9 \\
5 \cdot 3\end{array}$ & $\begin{array}{l}0.29 \\
0.18 \\
0.33\end{array}$ & $\begin{array}{l}0.25 \\
0.24 \\
0.12\end{array}$ & $\begin{array}{r}9.9 \\
6.7 \\
11.6\end{array}$ & $\begin{array}{l}8 \cdot 5 \\
9 \cdot 0 \\
4 \cdot 2\end{array}$ \\
\hline $\begin{array}{l}10: 90 \\
\text { Freon 11/12 }\end{array}$ & $0 \cdot 24$ & $0 \cdot 31$ & $5 \cdot 2$ & $5 \cdot 5$ & $0 \cdot 38$ & $0 \cdot 17$ & $14 \cdot 1$ & $6 \cdot 3$ \\
\hline $\begin{array}{l}50: 50 \\
\text { Freon 12/114 }\end{array}$ & 0.69 & 0.65 & $11 \cdot 0$ & $10 \cdot 0$ & 0.33 & $0 \cdot 14$ & $11 \cdot 0$ & $5 \cdot 0$ \\
\hline 30:70 & 0.63 & 0.65 & $11 \cdot 0$ & $11 \cdot 4$ & $0 \cdot 38$ & $0 \cdot 13$ & $13 \cdot 5$ & $4 \cdot 6$ \\
\hline
\end{tabular}

$A=$ first peak $; B=$ second peak . 


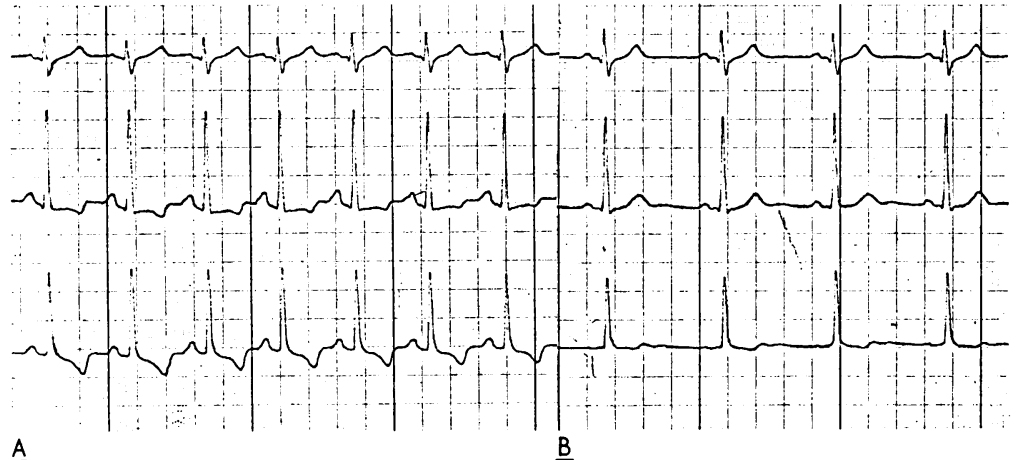

$\underline{A}$

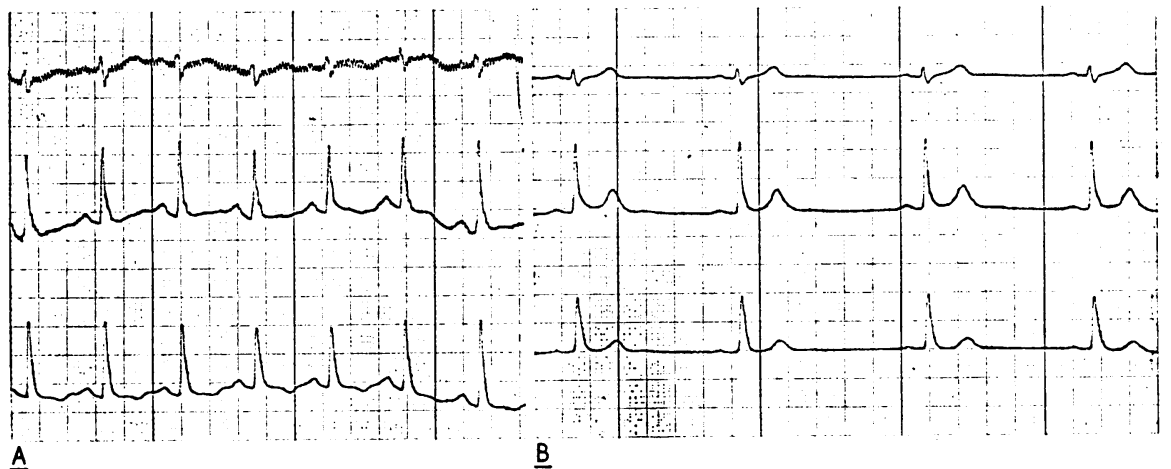

$\underline{A}$

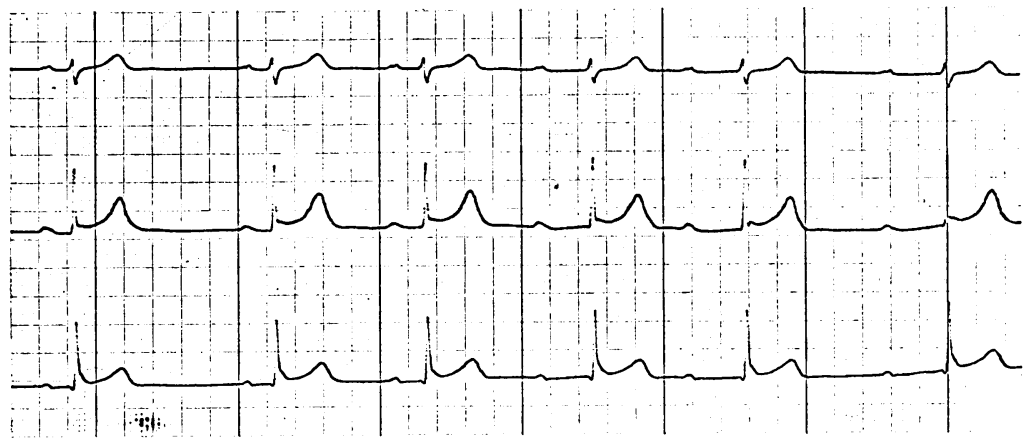

Fig. 3 Freon 11: exposures of 60 seconds, continuous recording

(A) ECG (standard leads) $15 \mathrm{~s}$ after exposure shows sinus tachycardia $(115 / \mathrm{min})$ and negative $T_{2}$ and $T_{3}$

(B) The same ECG 60 s later.

\section{Discussion}

The conflicting results of previously published studies have made it far from clear whether propellant gases adversely affect ventilatory capacity and cardiac function. In an attempt to answer this question we exposed a group of 10 healthy male subjects to freons $11,12,114$, to two mixtures of freon 11 and 12 (50:50 and 10:90), and to a mixture of freon 12 and
Fig. 4 Freon 11: exposure of $60 \mathrm{~s}$, continuous recording (A) ECG (standard leads) $\mathbf{4 0}$ s after exposure shows sinus tachycardia (112/min) and negative $T_{3}$ (B) The same ECG 80 s later.
Fig. 5 Freon 114: exposure of $60 \mathrm{~s}$, continuous recording ECG (standard leads) $50 \mathrm{~s}$ after the start of exposure shows the beginning of atrioventricular conductance prolongation (from 0.20 to $0.40 \mathrm{~s}$ ).
114 (30:70). We used higher concentrations than those employed in our previous studies (Valić et al., 1974; Žuškin et al., 1974) in which freon 12 had a very slight effect, and freon 11 a somewhat greater effect, on ventilatory capacity.

We have now shown that exposure to individual freons induces a biphasic reduction in ventilatory capacity (Figs. 1 and 2). The first fall occurs within a few minutes of exposure, with the second delayed 13- 
30 minutes after exposure. In our experiments, freon 11 appeared to have the greatest and freon 12 the least effect when individual gases were tested. However, the effects of mixtures proved to be far stronger than those of individual freons at similar total concentrations. It is interesting that we did not find any difference in the effect of 15 -second and 45second exposure periods. The maximum absolute reduction in MEF $50 \%$ was found to be greater than that of MEF $75 \%$, but the maximum relative reduction in MEF $75 \%$ was, on average, more pronounced. The constricting effects of freons appeared to be more pronounced in small airways.

Although the marked reduction in expiratory flow rate after exposure to the propellants studied was not clinically alarming, it raises the question whether frequent exposure and subsequent frequent marked reduction in ventilatory capacity could eventually induce permanent effects.

No serious cardiac effect, apart from one intermittent, first degree AV block, was found on short exposure to propellants, but most subjects developed respiratory sinus arrhythmia. Exposure for 60 seconds produced negative $T$ waves in two subjects and atrioventricular block in one. Bradycardia and increased variability of heart rate occurred in the majority of the other seven subjects. The changes observed were in accordance with those described in the literature, mainly referring to animal studies.

Although in most experiments no pathological cardiac changes were observed this does not imply complete absence of effect: arrhythmias, changes in the $T$ wave, and atrioventricular block were observed similar to those described in the rather scanty literature.

Our studies have shown that both respiratory and cardiac effects may follow inhalation of freons. It may well be that these effects are more serious in those who already have respiratory or cardiac disease. It is therefore advisable to use those aerosol sprays which contain freons in such a way that the amount inhaled is minimised.

\section{References}

Azar, A. A., Reinhardt, C. D., Maxfield, M. E., Smith, P. E., and Mullin, L. S. (1972). Experimental human exposures to fluorocarbon 12 (dichlorodifluoromethane). American Industrial Hygiene Association Journal, 33, 207-215.

Bass, M. (1970). Sudden sniffing death. Journal of the American Medical Association, 212, 2075-2079.

Bouhuys, A. (1974). Breathing. Grune and Stratton: New York and London.

Bouhuys, A., Hunt, V. R., Kim, B. M., and Zapletal, A. (1969). Maximum expiratory flow rates in induced bronchoconstriction in man. Journal of Clinical Investigation, 48, 1159-1168.

Brooks, S. M., Mintz, S., and Weis, E. (1972). Changes occurring after freon inhalation. American Review of Respiratory Diseases, 105, 640-643.

Lancet (1975). Editorial. Fluorocarbon aerosol propellants. Lancet, 1, 1073-1074.

Eagle, I. L., Putney, I. W., and Borzelleca, J. F. (1972). Cardiac rate and rhythm in mice affected by haloalkane propellants. Journal of the American Medical Association, 222, 786-789.

Flowers, N. C., and Horan, L. G. (1972). Nonanoxic aerosol arrhythmias. Journal of the American Medical Association, 219, 33-37.

Flowers, N. C., and Horan, L. G. (1973). Acid-base relationships and the cardiac response to aerosol inhalation. Chest, 63, 74-78.

Fraser, P. M., Speizer, F. E., Waters, S. D. M., Doll, R., and Mann, N. M. (1971). The circumstances preceding death from asthma in young people in 1968 to 1969. British Journal of Diseases of the Chest, 65, 71-84.

Joannides, M. (1971). Aerosols and aerosol propellants in asthma. Journal of the American Medical Association, 215, 119.

Paterson, J. W., Sudlow, M. F., and Walker, S. R. (1971). Blood-levels of fluorinated hydrocarbons in asthmatic patients after inhalation of pressurised aerosols. Lancet, 2, 565-568.

Paulet, G., and Chevrier, R. (1969). Modalités de l'élimination par l'air expiré du fluorane 11 inhalé. Étude chez l'homme et chez l'animal. Archives des Maladies Professionnelles, de Médecine du Travail et de Sécurité Sociale, 30, 251-256.

Paulet, G., Chevrier, R., Paulet, J., Duchene, M., and Chappet, J. (1969). De la rétention des fréons par les poumons et les voies aériennes. Étude faite chez l'homme et l'animal. Archives des Maladies Professionnelles, de Médecine du Travail et de Sécurité Sociale, 30, 101-102.

Paulet, G., and Desbrousses, S. (1969). Le dichlorotétrafluoroéthane. Toxicité aigue et chronique à moyen terme. Archives des Maladies Professionnelles, de Médecine du Travail et de Sécurité Sociale, 30, 447-492.

Peters, J. M., Mead, J., and Van Ganse, W. F. (1969). A simple flow-volume device for measuring ventilatory function in the field. American Review of Respiratory Diseases, 99, 617-622.

Silverglade, A. (1971). Aerosols and aerosol propellants in asthma. Journal of the American Medical Association, 215, 118.

Silverglade, A. (1972). Cardiac toxicity of aerosol propellants. Journal of the American Medical Association, 222, 827-829.

Silverglade, A. (1973). Fluorocarbon propellants in aerosols. Lancet, 1, 1325-1326.

Skurić, Z., Žuškin, E., and Valić, F. (1975). Effects of aerosols in common use on the ventilatory capacity of the lung. Internationales Archiv für Arbeitsmedizin, 34, 137-149.

Speizer, F. E., Doll, R., Heaf, P. J., and Strang, L. B. (1968). Investigation into use of drugs preceding death from asthma. British Medical Journal, 1, 339-343.

Stilinović, L., Duraković, Z., Vukadinović, D., and Beritić, T. (1972). The influence of dichlorodifluromethane (arcton 12, $\mathrm{CCl}_{2} \mathrm{~F}_{2}$ ) on the heart of rat. Arhiv za higijenu rada $i$ toksikologiju, 23, 19-27. (In Croat).

Taylor, G. J., and Harris, W. S. (1970). Cardiac toxicity of aerosol propellants. Journal of the American Medical Association, 214, 81-85.

Valić, F., and Žuškin, E. (1973). Pharmacological prevention of acute ventilatory capacity reduction in flax dust exposure. British Journal of Industrial Medicine, 30, 381-384.

Valić, F., Žuškin, E., Skurić, Z., and Denich, M. (1974). Effects of aerosols of common use on the ventilatory lung capacity. I. Change of $\mathrm{FEV}_{1 \cdot 0}$ in exposure to hair sprays. Acta medica iugoslavica, 28, 231-246. (In Croat). 
Zuškin, E., and Valić, F. (1972). Changes in flow-volume curves with exposure to active vegetable dust. Acta medica iugoslavica, 26, 189-199. (In Croat).

Žuškin, E., and Bouhuys, A. (1974). Acute airway response to hair spray preparations. New England Journal of Medicine, 290, 660-663.

Žuškin, E., Skurić, Z., and Valić, F. (1974). Effects of aerosols of common use on the ventilatory lung capacity. II. Changes in $\dot{\mathrm{V}}_{\max } 50 \% \mathrm{VC}$ and $\dot{\mathrm{V}}_{\max } 75 \% \mathrm{VC}$ in exposure to hair sprays. Acta medica iugoslavica, 28, 247-254. (In Croat).

Žuškin, E., Valić, F., Butković, D., and Bouhuys, A. (1975). Lung function in textile workers. British Journal of Industrial Medicine, 32, 283-288.

\section{The February 1977 Issue}

\section{THE FEBRUARY 1977 ISSUE CONTAINS THE FOLLOWING PAPERS}

Mortality experience of workers exposed to vinyl chloride monomer in the manufacture of polyvinyl chloride in Great Britain A. J. FOX AND P. F. COLLIER

Occupational formalin asthma D. J. HENDRICK AND D. J. LANE

Physical characteristics and ventilatory function of 404 commercial divers working in the North Sea W. A. CRosbie, M. B. ClaRKe, R. A. F. COX, N. K. I. MCIVER, I. K. ANDERSON, H. A. EVANS, G. C. LIDDLE, J. L. COWAN, C. H. BROOKINGS, AND D. G. WATSON

Urinary mercury excretion and proteinuria in pathology laboratory staff W. K. STEWART, H. A. GUIRGIS, J. SANDERSON, AND W. TAYLOR

The effect of metal ions on the activity of $\delta$-aminolevulinic acid dehydratase J. THOMPSON, D. D. JONES, AND W. H. BEASLEY
Retention, distribution, and excretion of lead by the rat after intravenous injection A. MORGAN, A. HOLMES, AND J. C. EVANS

Trichloroethylene exposure. Simulation of uptake, excretion, and metabolism using a mathematical model J. G. FERNÁNDEZ, P. O. DROZ, B. E. HUMBERT, AND J. R. CAPEROS

A pharmacokinetic model to study the excretion of trichloroethylene and its metabolites after an inhalation exposure A. SATO, T. NAKAJIMA, Y. FUJIWARA, AND N. MURAYAMA

Book reviews

Notices

Information section

Copies are still available and may be obtained from the PUBLISHING MANAGER, BRITISH MEDICAL ASSOCIATION, TAVISTOCK SQUARE, LONDON, WClH 9JR, price $£ 3 \cdot 75$, (USA $\$ 9 \cdot 20$ ) including postage 